\title{
Evaluation of the environmental quality of a protected riparian forest in Southern Brazil
}

\author{
Evaluación de la calidad ambiental de un área de bosque ribereño protegido del sur de Brasil
}

\author{
Márcia Isabel Käffer ${ }^{\text {a*, }}$, Suzana Maria de Azevedo Martins a \\ *Corresponding author: ${ }^{a}$ Museu de Ciências Naturais da Fundação Zoobotânica do Rio Grande do Sul, C.P. 1188, \\ Porto Alegre, RS, CEP 90690-000, Brazil , tel.:+555133202068; fax: +555133346765, m.kaffer@terra.com.br
}

\begin{abstract}
SUMMARY
Environmental Protection Areas (EPA) are of extreme importance for species conservation and establishment. We investigated different areas of riparian forests in the Environmental Protection Area of Ibirapuitã, southern Brazil. We analyzed the environmental quality of these areas by studying the lichen community and using the index of atmospheric purity (IAP) with the environmental classification factor (ECF) as the correction factor. The lichen community was analyzed in 12 riparian forest stands located in the southern region of EPA. Lichens were registered on 60 tree barks, from $50 \mathrm{~cm}$ to $150 \mathrm{~cm}$ above the ground, on both north and south sides. A cluster analysis was used to test whether there were changes in lichen species similarity among communities from each forest vegetation stands. A total of 193 lichen species were registered. The stands were classified into poor-lichen, transition zone, and normal for lichen development. The cluster analysis showed distinct groups, demonstrating differences in species composition among the stands. Indicator lichen species were registered in $80 \%$ of the studied stands. In the most conserved areas, higher species richness and a greater number of fruticose species were registered, besides the presence of key species such as the genus Lobaria. The conservation of forest areas in environmental protection areas is essential for biodiversity conservation. Our results confirm the usage of the index of atmospheric purity with ECF to evaluate environmental quality of forest areas.
\end{abstract}

Key words: EPA of Ibirapuitã, protected, conservation, corticolous lichens, IAP.

\section{RESUMEN}

Las áreas de protección ambiental (APA) son de importancia para la conservación de las especies y su establecimiento. Se investigaron diferentes áreas de bosques ribereños en el área de protección ambiental de Ibirapuitã, sur de Brasil. Se analizó la calidad ambiental de estas áreas de la comunidad liquénica, utilizando el índice de pureza atmosférica (IPA), con el factor de clasificación ambiental (FCA) como el factor de corrección. La comunidad liquénica fue analizada en 12 sitios del bosque ribereño ubicados en la región sur de la APA. Se registraron los líquenes en 60 árboles, de $50 \mathrm{~cm}$ a $150 \mathrm{~cm}$ sobre suelo, en las exposiciones norte y sur. Se utilizó el análisis de conglomerados para verificar cambios en la similitud de especies liquénicas entre los diferentes sitios del bosque. Se registró un total de 193 especies de líquenes. Los sitios fueron clasificados en zonas pobres, de transición y normal para el desarrollo de los líquenes. El análisis de conglomerados mostró grupos distintos, lo que demuestra diferencias en la composición de especies entre los sitios del bosque. En el 80 \% de los sitios se registraron especies de líquenes indicadoras. En las zonas más conservadas se registró mayor riqueza de especies, mayor número de especies fructicosas, además de la presencia de especies del género Lobaria. La preservación de las áreas de protección ambiental es esencial para la conservación de la biodiversidad. Los resultados obtenidos confirman que el uso del índice de pureza atmosférica con FCA permite evaluar la calidad ambiental de las áreas forestales.

Palabras clave: APA de la Ibirapuitã, protegido, conservación, líquenes cortícolas, IPA.

\section{INTRODUCTION}

Protected areas are of extreme contribution to the Earth's natural and cultural research context, since they aim at conserving representative samples of natural regions and the biological diversity associated with them (Backes 2012). Tropical forests and associated systems from the Neotropical region represent $7 \%$ of the planet surface. The Brazilian territory, which is mainly tropical, concentrates in its many biomes the greatest biodiversity (Backes 2012).

The temperate grasslands from southern South America (Pampa Biome) were originally composed by an area of more than one million square kilometers, but only a little percentage remains in its natural state and the few areas left are threatened by agricultural intensification (WBW 2012). This biome harbors a great biodiversity, comprising around two thousands of plant species (Boldrini 2009); however, knowledge about other biological groups is still scarce.

In this context, changes in forest landscapes and management practices highly influence biodiversity, for both species richness and population size. Lichens, especially species from old forests, are more affected among the groups of organisms, reacting even to small changes in their habitat structure (Richardson and Cameron 2004). They are 
important epiphytic components in forest environments, dominating more than $8 \%$ of the terrestrial area of our planet (Hale 1983, Valencia and Ceballos 2002). These organisms are used as indicators of forest succession stages, since they are more developed in older forests than in younger forests, which can demonstrate whether the forest system remained intact over time (McCune 1993, Esseen et al. 1996, Tuvi et al. 2011, Hauck et al. 2013, Nascimbene et al. 2013).

For the area of Pampa Biome there are no studies about lichens and since they are pioneer organisms for environmental colonization (Valencia and Ceballos 2002) and also sensitive to environmental changes (Dyer and Letourneau 2007, Giordani et al. 2012), it is possible to evaluate environmental conditions through this group of organisms, as a measure of forest quality. Most studies carried out on lichens aiming at evaluating the conservation stage in forest environments (Lidén et al. 2004, Cáceres et al. 2007, 2008, Käffer et al. 2009, Tuvi et al. 2011, Boudreault et al. 2013, Hauck et al. 2013, Nascimbene et al. 2013, Estrabou et al. 2014) are based on the evaluation of species richness and diversity and/or on key species from preserved environments. Thus, our hypothesis is that lichen community occurring in riparian forest areas in an environmental protection area (EPA of Ibirapuitã) may indicate the environmental quality of these regions, mapping better areas for lichen development by using the index of atmospheric purity (IAP) (Le Blanc and De Sloover 1970) with the environmental classification factor (ECF) as the correction factor, proposed by Käffer et al. (2011). Hence, this study had as main objectives: a) to evaluate different riparian forest areas which are inserted in an environmental protection area (APA) in Pampa Biome indicating the environmental quality of these regions and identify the best zones for lichen development and, b) to identify indicator species of more conserved forest environments.

\section{METHODS}

Study area. The environmental protection area of Ibirapuitã (EPA of Ibirapuitã) is classified as a conservation unit for sustainable use and its territory is distributed in four municipalities of Rio Grande do Sul state, Brazil: Alegrete (15\%), Quaraí (12 \%), Rosário do Sul (16 \%) and Santana do Livramento (57\%). The climate is classified as subtropical hot, Cfa type according to the updated Köeppen classification, the average temperature is $18.6^{\circ} \mathrm{C}$ and the average rainfall is $1,500 \mathrm{~mm}^{-1} \mathrm{yr}^{-1}$ (Backes 2012). The main vegetation type is grassland, but along the rivers there are also riparian forests and remnants of slope forest in other areas, as well as some forest patches (Backes 2012, Andrade 2013). This study was carried out in the southern region of the EPA, in Santana do Livramento (29 05' S and 55 $29^{\circ}$ ' W), during the period comprised between 2011 and 2013, in twelve stands of riparian forest: Lolita Farmland (LO1LO6); São Maurício Farmland (MA1-MA3) and Rincão Bonito Farmland (RB1-RB3) (figure 1, table 1).
Table 1.Geographical characteristics of the stand at the EPA of Ibirapuitã.

Características geográficas de los sitios del APA de Ibirapuitã.

\begin{tabular}{|c|c|c|}
\hline $\begin{array}{l}\text { Riparian forest } \\
\text { stand }\end{array}$ & Coordinates & $\begin{array}{l}\text { Altitude } \\
\text { (m) }\end{array}$ \\
\hline LO1 & $30^{\circ} 46^{\prime} 48.1$ 'S 55०36’32.6”W & 244 \\
\hline $\mathrm{LO} 2$ & $30^{\circ} 46^{\prime} 77.0^{\prime \prime} \mathrm{S} 55^{\circ} 36^{\prime} 44.6^{\prime \prime} \mathrm{W}$ & 247 \\
\hline LO3 & $30^{\circ} 45^{\prime} 99.6^{\prime \prime} \mathrm{S} 55^{\circ} 36^{\prime} 16.6^{\prime \prime} \mathrm{W}$ & 770 \\
\hline $\mathrm{LO} 4$ & $30^{\circ} 45^{\prime} 92.4^{\prime \prime} \mathrm{S} 55^{\circ} 36^{\prime} 38.2^{\prime \prime} \mathrm{W}$ & 792 \\
\hline LO5 & $30^{\circ} 46^{\prime} 77.2 " \mathrm{~S} 55^{\circ} 36^{\prime} 05.6 ” \mathrm{~W}$ & 787 \\
\hline LO6 & $30^{\circ} 46^{\prime} 78.9^{\prime \prime} \mathrm{S} 55^{\circ} 35^{\prime} 69.7{ }^{\prime \prime} \mathrm{W}$ & 883 \\
\hline MA1 & $30^{\circ} 37^{\prime} 77.9^{\prime \prime} \mathrm{S} 55^{\circ} 33^{\prime} 92.9^{\prime \prime} \mathrm{W}$ & 871 \\
\hline MA2 & $30^{\circ} 37^{\prime} 82.1 ” \mathrm{~S} 55^{\circ} 34^{\prime} 09.3 ” \mathrm{~W}$ & 972 \\
\hline MA3 & $30^{\circ} 37^{\prime} 52.1^{\prime \prime} \mathrm{S} 55^{\circ} 33^{\prime} 82.6^{\prime \prime} \mathrm{W}$ & 862 \\
\hline RB1 & $30^{\circ} 34^{\prime} 29.5^{\prime \prime} \mathrm{S} 55^{\circ} 31^{\prime} 63.8^{\prime \prime} \mathrm{W}$ & 674 \\
\hline RB2 & $30^{\circ} 33$ '80.7'S 55'31'46.4”'W & 524 \\
\hline RB3 & $30^{\circ} 33^{\prime} 88.7^{\prime \prime} \mathrm{S} 55^{\circ} 31^{\prime} 01.6{ }^{\prime \prime} \mathrm{W}$ & 540 \\
\hline
\end{tabular}

Sampling and identification. At each stand of the riparian forest (LO, MA and RB) five host trees, with DBH (diameter at breast height) over $7.3 \mathrm{~cm}$ were randomly sampled comprising a total of 60 host trees. Each host tree was identified to species and the DBH was recorded (table 2). The analyzed riparian forest stands were characterized by the presence of medium and large trees, understory and closeness to a watercourse. These stands also had some agropastoral influence, mainly livestock (cattle and/or sheep).

Lichens were registered on the tree barks from $50 \mathrm{~cm}$ to $150 \mathrm{~cm}$ above the ground, in both north and south sides of the trunk. For lichen mapping, a total of five pieces of transparent plastic with $20 \mathrm{~cm}$ x $20 \mathrm{~cm}$ each (acetate method) were disposed along the host-tree trunk (both sides) (figure 2). All sampled species were identified in situ or collected for posterior confirmation at the laboratory.

Lichen identification was carried out through the observation of anatomical sections of the thallus and fructifications, by using stereoscopic and optical microscopes. Some external characteristics were also analyzed, such as color and thallus aspect, length and width of lobes, presence of picnids and aspect of rhizines, cilia and apothecia. Spottests reaction with potassium hydroxide $20 \%(\mathrm{KOH})$, calcium hypochlorite $\left(\mathrm{CaClO}_{2}\right)$, paraphenylenediamine $(\mathrm{P})$, lugol solution (I reaction) and fluorescence under UV-light (long wave) were used to determine the presence of acid substances in the cortex, medulla, hymenium, ascus and ascospores. Also for identification purposes, specialized literature for each taxonomic group was checked; besides materials from the Herbarium Prof. Dr. Alarich Schultz Herbarium (HAS) at the Zoobotanical Foundation of Rio 


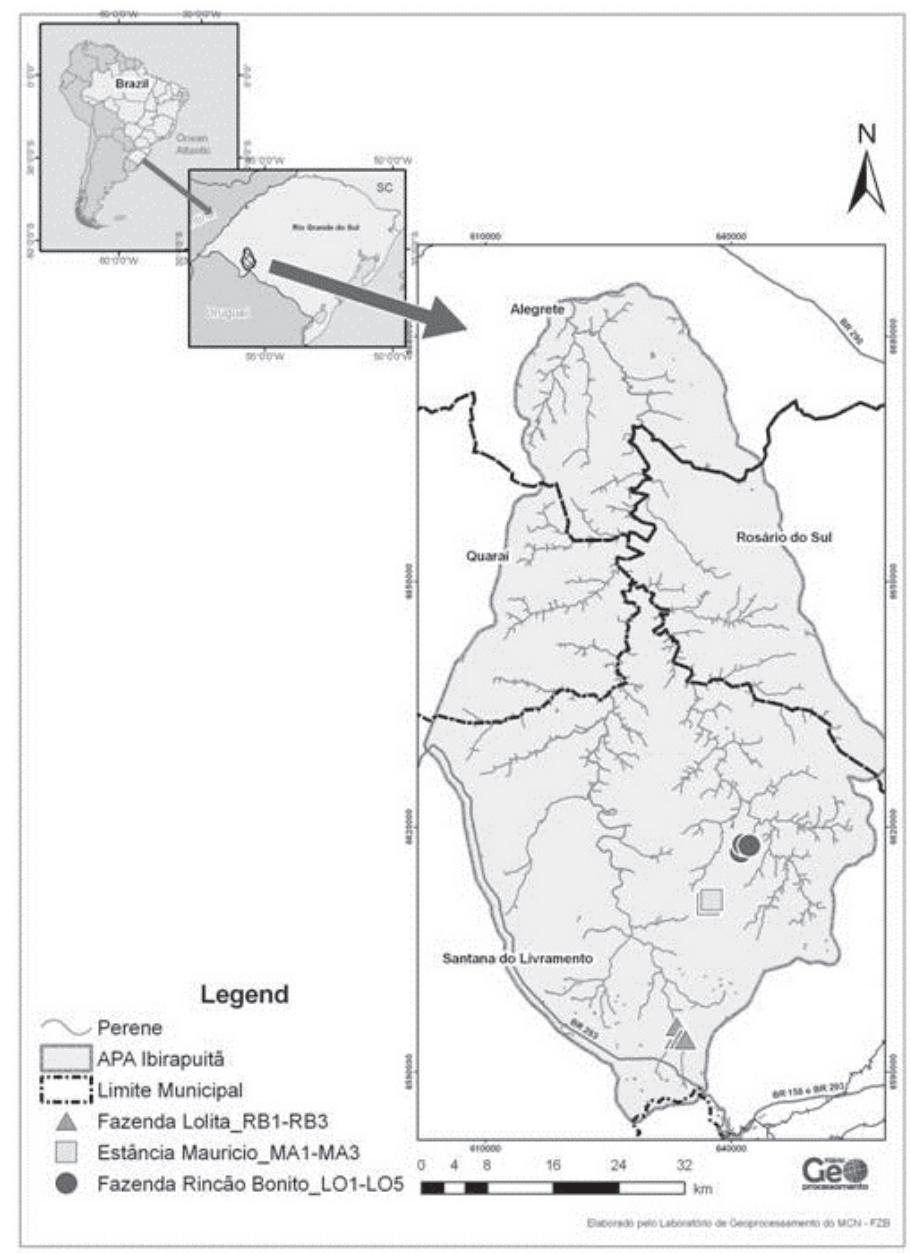

Figure 1. Map of the study stands at the environmental protection area of Ibirapuitã (EPA of Ibirapuitã), southern Brazil. Mapa de los sitios de estudio en la área de protección ambiental (APA de Ibirapuitã), sur de Brasil.

Table 2. Host trees characteristics and frequency in the riparian forest stand at the EPA of Ibirapuitã. Características y frecuencia de los árboles en los sitios del APA de Ibirapuitã.

\begin{tabular}{|c|c|c|c|c|}
\hline Family & Species & $\begin{array}{l}\text { Number of } \\
\text { individuals }\end{array}$ & $\begin{array}{l}\text { DBH } \\
(\mathrm{cm})\end{array}$ & Riparian forest stand \\
\hline \multirow[t]{3}{*}{ Anacardiaceae } & Lithraea brasiliensis Marchand & 1 & 15.9 & $\mathrm{LO} 2$ \\
\hline & Lithraea molleoides (Vell.) Engl. & 2 & $10.2-12.7$ & MA2 \\
\hline & Schinus lentiscifolius Marchand & 1 & 12.4 & LO6 \\
\hline \multirow[t]{2}{*}{ Euphorbiaceae } & Sebastiania brasiliensis Spreng & 4 & 7.6-13.1 & LO1, MA3, RB2 \\
\hline & Sebastiania commersoniana (Baill.) L.B. Sm. et Downs & 31 & $9.2-19.6$ & MA1, MA3, RB1, RB2, RB3 \\
\hline \multirow[t]{2}{*}{ Lauraceae } & Ocotea acutifolia(Nees) Mez & 3 & 13.1-14.5 & LO2, LO5 \\
\hline & Ocotea pulchella (Nees) Nez & 1 & 31.2 & RB1 \\
\hline Myrtaceae & Blepharocalys salicifolius (Kunth) O.Berg. & 1 & 21.3 & $\mathrm{LO} 2$ \\
\hline Myrsinaceae & Myrsine coriacea (Sw.) R.Br. & 6 & $11.5-23.1$ & MA1, MA2, MA3 \\
\hline Sapotaceae & Pouteria salicifolia (Spreng.) Radlk. & 7 & $9.6-13.2$ & LO4, LO5 \\
\hline Styracaceae & Styrax leprosus Hook. et Arn. & 1 & 10.4 & $\mathrm{LO} 2$ \\
\hline Verbenaceae & Aloysia gratissima (Gillies et Hook) Tronc & 2 & 7.3 & LO3 \\
\hline
\end{tabular}




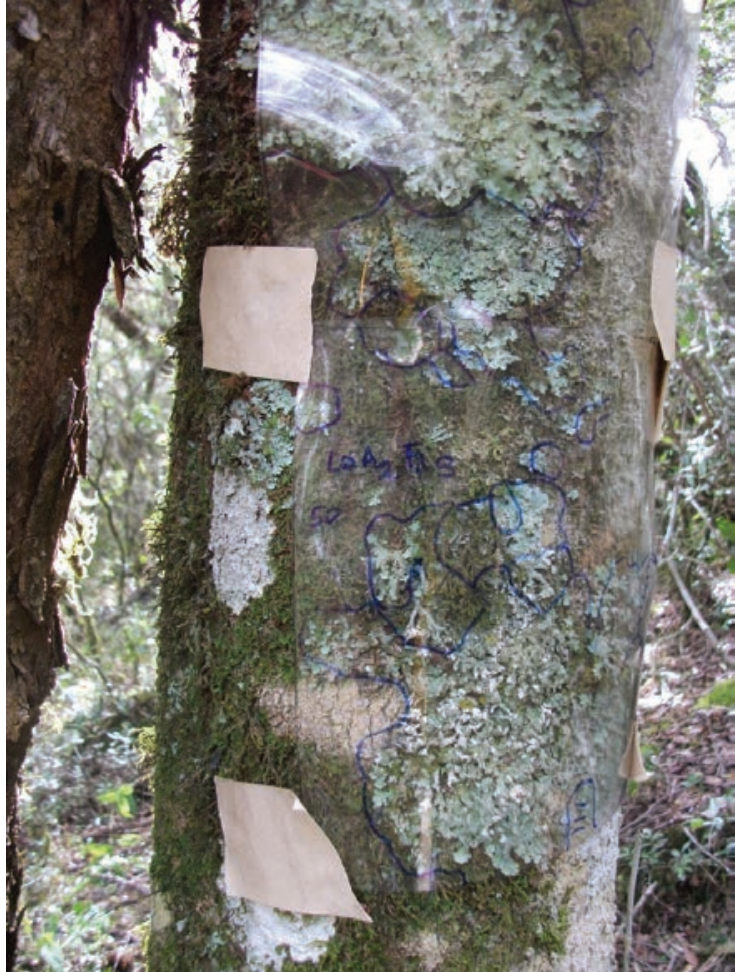

Figure 2. Acetate method used for the lichen mapping in stands of riparian forest.

Método del acetato utilizado para el mapa de los líquenes de los sitios del bosque ribereño.

Grande do Sul State, Brazil. The collected material was herborized and stored in this Herbarium catalogue.

Environmental quality and forest areas. Data analyses only considered species whose thalli represented at least $0.5 \mathrm{~cm}$ in each of the five host-trees analyzed in each area. The coverage estimate for each lichen species was carried out by summing the total coverage of all thalli present in each of the five transparent pieces from all host trees, in each stand of riparian forest.

Data analyses. The environmental quality of the riparian forest areas was analyzed through the index of atmospheric purity (IAP) (Le Blanc and De Sloover 1970) with the environmental classification factor (ECF) as the correction factor, as proposed by Käffer et al. (2011). For each riparian forest stand the IAP with ECF was used, considering frequency data, coverage and the environmental index of each species. The environmental classification factor (ECF) incorporates IAP parameters as a correction factor through a scale of coverage percentage of the morphological lichen groups.

Species richness was considered as the total number of lichen species occurring in the five host trees that were analyzed in each riparian forest stand. In order to investigate possible changes in species similarity among lichen com- munities present in each stand, a cluster analyses method based on the relative Sørensen coefficient of dissimilarity as a classification method was used, and a flexible beta $=0.25$ was used as the clustering algorithm (McCune et al. 2002).

The indicator species analysis was performed to detect species that can be classified as typical of a given stand in a riparian forest. For this analysis, a Monte-Carlo test was performed on the frequency and abundance data of the lichen species (McCune et al. 2002). All statistical analyses were carried out with the statistics software PC-ORD 6.0 (2010).

\section{RESULTS}

A total of 193 lichenized fungi from 55 genera were recorded (Appendix). Among them, only $6.7 \%$ were colonized by cyanobacteria and $93.3 \%$ by chlorophytes.

Environmental quality of the riparian forest areas. The index of atmospheric purity with the ECF in the riparian forest stands varied from 8.1 to 64.2 . They were classified into three different zones for the development of the lichenized mycota: two lichen-poor areas (LO2 and LO6), five transition areas (LO1, LO3, LO4, LO5 and MA2) and five normal areas for lichen development (MA1, MA3, RB1, $\mathrm{RB} 2$ and RB3). The analyzed riparian forest stands were classified into five zones, considering a scale variation from 1.0 to above 75.5, established by Le Blanc and De Sloover (1970) for the IAP: Zone I - lichen-absence (1.0 to 5.5), Zone II - lichen-poor (5.6 to 15.5), Zone III - transition area (15.6 to 35.5), Zone IV - normal (35.6 to 75.5) and Zone V - excellent (higher than 75.6) (table 3).

Lichen richness was higher in the riparian forest stand RB2 (64 species) than in other areas. The riparian forest stands LO6 and LO4 showed the lowest species richness (both with 27) (table 3).

Lichen community patterns among riparian forest stands. The cluster analysis showed five distinct groups and demonstrated that there were differences in species composition among the riparian forest stands (figure 3). Stands LO1 and MA2 were characterized as lichen-poor and lichen transition areas, both with similar richness and same species composition, mainly composed by species from Graphidaceae. Stands LO6 and MA1 were classified as poor and normal for lichen development. However, these areas showed similar composition, especially with species from the genus Leptogium and Lobaria. Stands MA3 and RB1, as well as RB2 and RB3, were characterized as normal zones for lichen development. In these areas the lichen community was sampled on the same host tree species and they showed similar lichen species richness, composition and coverage, mainly constituted by representatives from Parmeliaceae and Physciaceae. And finally, stands LO4 and LO5 were classified as transition areas for lichen development, with the same lichen species richness and similar composition, with the predominance of species from Parmeliaceae. 
Table 3. Values for the index of atmospheric purity (IAP) and richness at each riparian forest stand at the environmental protection area of Ibirapuitã.

Índice de la pureza atmosférica (IPA) y riqueza en las áreas del bosque ribereño del área de protección de Ibirapuitã.

\begin{tabular}{crcc}
\hline Riparian forest stand & IAP & Classification & Richness \\
\hline LO1 & 27.4 & transition & 31 \\
LO2 & 8.1 & lichen-poor & 46 \\
LO3 & 31.9 & transition & 31 \\
LO4 & 18.8 & transition & 27 \\
LO5 & 26.1 & transition & 34 \\
LO6 & 8.5 & lichen-poor & 27 \\
MA1 & 43.8 & normal & 50 \\
MA2 & 26.6 & transition & 55 \\
MA3 & 42.3 & normal & 40 \\
RB1 & 50.5 & normal & 50 \\
RB2 & 64.2 & normal & 64 \\
RB3 & 55.0 & normal & 53 \\
\hline
\end{tabular}

Lichen species as indicators of riparian forest. There were indicator species of riparian forests in around $80 \%$ of the analyzed areas. Seven species were considered as indicator species of riparian forests according to the richness values of each species. The foliose species revealed the highest predominance (five), while the crustose and fruticose group registered only one species, representing $20 \%$ of all specimens. The taxa with the highest indication values (IV), considering statistically significant values only, were: Dirinaria picta (Sw.) Clem. et Shear (IV=80.7, $P=0.0270)$, Graphis sp. 1 (IV $=72.6, P=0.0572)$, Нypo- trachyna livida (Taylor) Hale ( $\mathrm{IV}=74.7, P=0.0520)$, Leptogium isidiosellum (Riddle) Sierk. (IV $=100, P=0.0060$ ), Lobaria discolor (Bory ex Delise) Hue (IV=75.0, $P=0.0546$ ), Parmelinopsis minarum (Vainio) Elix et Hale (IV $=98.6, P=0.0056)$ and Usnea angulata Ach. $(\mathrm{IV}=75.0, P=0.0546)$.

\section{DISCUSSION}

The application of the index of atmospheric purity with the ECF in riparian forest areas revealed the presence of some changed environments and others in better conservation status in the southern region of the EPA of Ibirapuitã, which corroborates our initial hypothesis.

The most changed areas (LO1, LO3, LO4, LO5 and LO6) registered in this study were characterized as regions with sparse woody vegetation, low lichen species richness, smaller number of taxa of the fruticose morphologic group and were then classified as transition and poor zones for lichen development. The presence of the fruticose morphologic group is associated with less modified areas (Büdel and Scheiddeger 2008). The most preserved areas (MA1, MA3, RB1, RB2 and RB3) were characterized by possessing denser vegetation and being closer to watercourses, which provides them a different microclimate when considering the other regions. These zones were classified as normal for lichen development, with higher richness values and the presence of species that are characteristic of preserved environments, such as Lobaria erosa (Eschw.) Trev., Lobaria discolor (Bory ex Delise) Hue and species from genus Chapsa and Usnea. In these areas, especially in the stands MA1 and RB2, we found some lichens that were new species for science, as well as new records for the southern hemisphere, Brazil and the state of Rio Grande do Sul (Kitaura et al. 2014, Aptroot et al. 2014, Käffer et al. 2014).

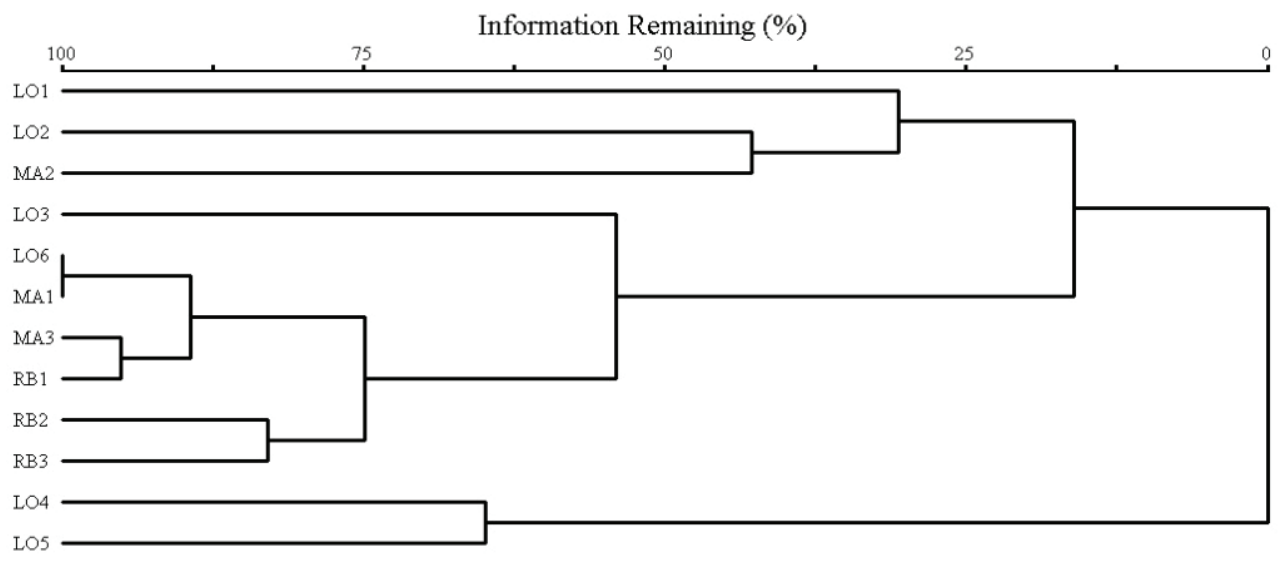

Figure 3. Cluster of similarity composition based on the relative Sørensen coefficient of dissimilarity. Riparian forest stand represent: LO1-LO6 = Lolita Farmland, MA1-MA3 = São Maurício Farmland and RB1-RB3 = Rincão Bonito Farmland.

Análisis de cluster, considerando la composición, con base en el coeficiente de la disimilitud relativa de Sørensen. Las áreas de bosque ribereño representan: LO1-LO6 = hacienda Lolita, MA1-MA3 = hacienda São Maurício y RB1-RB3 = hacienda Rincão Bonito. 
Most studies carried out in conservation unities using lichens report the changes in forest areas, especially related to management practices (Käffer et al. 2009, Giordani et al. 2012, Boudreault et al. 2013, Király et al. 2013) and habitat fragmentation (Tuvi et al. 2011, Nascimbene et al. 2013). In our study, the changes observed in different forest areas are especially related to the management made in the area, due to the presence of cattle and sheep.

The EPA of Ibirapuitã is composed by private properties (Backes 2012) presenting distinct forms of economic development, influenced by the dimensions of each rural property. These properties are based on primary production (extensive livestock) and grain production (Chomenko 2008).

Habitat fragmentation, degradation or destruction and the consequent magnification of the human space and of its activities consist in negative actions in relation to the biodiversity (Backes 2012). The changes occurred in the forest areas can cause changes in lichen community structure and composition. These changes were verified in different forest areas, especially in species composition. The host tree characteristics could also have influenced the results found, mainly in relation to bark structure, DBH and the tree position in the forest areas. We observed that some host trees had higher light incidence than others. The community structure of epiphytic lichens can be determined by its host trees characteristics (Lõhmus et al. 2007). Trees barks that suffer shredding can also inhibit lichen growth (Topham 1977). The host tree level has been an important variable explaining lichen species composition and richness (Jüriado et al. 2009). The diameter of the tree is correlated to space availability for lichen species development and it is known as a key factor for community structure (Belinchon et al. 2007). According to Lie et al. (2009) it is possible that physical-chemical bark characteristics change with time and that an old substrate can provide a different substrate in a young tree.

In all the studied forest areas, representatives of families Parmeliaceae and Physciaceae were frequent, mainly in the regions with sparse vegetation. Species from these families are characteristic of forest edges, areas with higher luminosity and wind, and they are well represented in Brazilian landscapes (Marcelli 1998). In the areas closer to the watercourse, with denser vegetation, species from family Collemataceae were abundant, highlighting the genus Leptogium, with nine species. Representatives from this family are characteristic of humid and shaded environments (Wolseley 1991).

The presence of species from genus Lobaria was registered in more preserved areas of this study, with high coverage values. Species from this genus have been cited as indicators of preserved forest ecosystems and associated with forest areas of high ecological continuity (Campbell and Fredeen 2004, Liira and Sepp 2009). Their presence is also associated with a variety of other rare or endangered species, and hence they can be considered as umbrella species (Scheidegger and Werth 2009, Nascimbene et al. 2010).

\section{CONCLUSIONS}

The conservation of forest areas in Environmental Protection Areas is fundamental for biodiversity preservation. However, anthropic influences may cause loss of species that are characteristics from these environments. The results here presented confirm the use of the index of atmospheric purity with the environmental classification factor to evaluate the environmental quality in forest areas. The presence and the high coverage values of species from the genus Lobaria showed the good conservation status of some of the analyzed areas; the occurrence of this species also reinforces the importance of conserving riparian forests in this region.

\section{ACKNOWLEDGMENTS}

We thank the lichenologist Dr. Marcos Kitaura for the identification of some Leptogium species from the Botanic Institute of UNESP and also Felipe C. Maciel, Renata V. Dantas, Fabiane Lucheta and Natália M. Koch for their help with the fieldwork. Lastly, we thank the Museu de Ciências Naturais for offering its structures for laboratory activities and the Geoprocessing Laboratory for helping to compile maps, both from Fundação Zoobotânica do Rio Grande do Sul. We also thank the Conselho Nacional de Desenvolvimento Científico e Tecnológico - CNPq (process number 160115/2012-4) for the Post-Doctoral fellowship.

\section{REFERENCES}

Aptroot, A, HJM Sipman, M Käffer, SM de A Martins, LI Ferraro, MES Cáceres. 2014. A world key to Stirtonia (Arthoniaceae), with three new Stirtonia species and one new Crypthonia from the Neotropics. The Lichenologist 46: 1-7.

Andrade RO. 2013. Intervenções sustentáveis. Revista da FAPESP on line, 206, São Paulo, p.52. Available from http:// www.revistapesquisa.fapesp.br/ BiotaFapesp.pdf. Accessed 19 Aug. 2013.

Backes A. 2012. Áreas protegidas no estado do Rio Grande do Sul: o esforço para a conservação. Pesquisas Botânica 63: 225-355.

Belinchòn, R, I Martinez, A Escudero, G Aragòn, F Valladares. 2007. Edge effects on epiphytic communities in a Mediterranean Quercus pyrenaica forest. Journal Vegetation Science 18: 81-90.

Boudreault C, D Coxson, Y Bergeron, S Stevenson, M Bouchard. 2013. Do forests treated by partial cutting provide growth conditions similar to old-growth forests for epiphytic lichens? Biological Conservation 159: 458-467.

Boldrini I. 2009. A flora dos Campos do Rio Grande do Sul. In VD Pillar, SC Müller, ZMS Castilhos, AVA Jacques eds. Campos Sulinos: Conservação e Uso Sustentável da Biodiversidade. Brasilia, Brazil. Ministério do Meio Ambiente. p. 63-77.

Büdel B, C Scheiddege. 2008. Thallus morphology and anatomy. In Nash III TH ed. Lichen Biology, 2nd ed., Cambridge, England. University Press. p. 40-69. 
Campbell J, AL Fredeen. 2004. Lobaria pulmonaria abundance as an indicator of macrolichen diversity in Interior CedarHemlock forests of east-central British Columbia. Canadian Journal of Botany 82: 970-982.

Chomenko L. 2008. Um panorama sobre o cultivo de monocultura de árvores. Cadernos IHU em formação 4(27): 28-42.

Esseen PA, KE Renhorn, RB Pettersson. 1996. Epiphytic lichen biomass in managed and old-growth boreal forests: effect of branch quality. Ecology Applied 6: 228-238.

Estrabou C, C Quiroga, JM Rodriguez. 2014. Lichen community diversity on a remnant forest in South of Chaco region (Cordoba, Argentina). Bosque 35(1): 49-55.

Giordani P, G Brunialti, G Bacaro, J Nascimbene. 2012. Functional traits of epiphytic lichens as potential indicators of environmental conditions in forest ecosystems. Ecological Indicators 18: 413-420.

Hale ME. 1983. The biology of lichens. Baltimore, USA. Edward Arnold. 190 p.

Hauck M, U Bruyn, C Leuschner. 2013. Dramatic diversity losses in epiphytic lichens in temperate broad-leaved forests during the last 150 years. Biological Conservation 157: 136-145.

Jüriado I, J Liira. 2009. Distribution and habitat ecology of the threatened forest lichen Lobaria pulmonaria in Estonia. Folia Cryptog. Estonica 46: 55-65.

Käffer MI, G Ganade, MP Marcelli. 2009. Lichen diversity and composition in Araucaria forests and tree monocultures in southern Brazil. Biodiversity and Conservation 18: 35433561.

Käffer MI, SM de A Martins, C Alves, VC Pereira, J Fachel, VMF Vargas. 2011. Corticolous lichens as environmental indicators in urban areas in southern Brazil. Ecological Indicators 11: 1319-1332.

Käffer MI, NM Koch, A Aptroot, SM de A Martins. 2014. New records of corticolous lichens for South America and Brazil. Plant Ecology and Evolution, in press. doi: dx.doi. org/10.5091/plecevo.2015.961

Király I, J Nascimbene, F Tinya, P Ódor. 2013. Factors influencing epiphytic bryophyte and lichen species richness at different spatial scales in managed temperate forests. Biodiversity and Conservation 22: 209-223.

Kitaura JM, MI Käffer, MP Marcelli, SM de A Martins. 2014. A new hairy Leptogium (section Mallotium) from Rio Grande do Sul State, Brazil. Hoenhea 41: 303-306.

Le Blanc FSC, J De Sloover. 1970. Relation industrialization and the distribution and growth of epiphytic lichens and mosses in Montreal. Canadian Journal of Botany 48(8): 1485-1496.

Lidén M, M Pettersso, U Bergsten, T Lundmark. 2004. Artificial dispersal of endangered epiphytic lichens: a tool for conservation in boreal forest landscapes. Biological Conservation 118: 431-442.

Lie, M, H, U Arup, J A Grytnes, M Ohlson. 2009. The importance of host tree age, size and growth rate as determinants of epiphytic lichen diversity in boreal spruce forests. Biodiversity and Conservation 18: 3579-3596.

Liira J, T Sepp. 2009. Indicators of structural and habitat natural quality in boreo-nemoral forests along the management gradient. Annals Botanny Fennici 46: 308-325.

Lõhmus A, P Lõhmus, K Vellak. 2007. Substratum diversity explains landscape-scale co-variation in the species-richness of bryophytes and lichens. Biological Conservation 135: 405-414.

Marcelli MP 1998. History and current knowledge of Brazilian Lichenology. In Marcelli MP, MRD Seaward eds. Lichenology in Latin America: history, current knowledge and applications. São Paulo, Brazil. CETESB. p. 25-47.

McCune B. 1993. Gradients in epiphyte biomass in three Pseudotsuga-Tsuga forests of different ages in western Oregon and Washington. Bryologist 96: 405-411.

McCune B, JB Grace, DL Urban. 2002. Analysis of Ecological Communities. MjM Software, Gleneden Beach, OR, USA.

Nascimbene J, G Brunialti, S Ravera, L Frati, G Caniglia. 2010. Testing Lobaria pulmonaria (L.) Hoffm. as an indicator of lichen conservation importance of Italian forests. Ecological Indicators 10: 353-360.

Nascimbene J, R Benesperi, G Brunialti, I Catalano, MD Vedove, M Grillo, D Isocrono, E Matteucci, G Potenza, D Puntillo, M Puntillo, S Ravera, G Rizzi, P Giordani. 2013. Patterns and drivers of b-diversity and similarity of Lobaria pulmonaria communities in Italian forests. Journal Ecology 101: 493-505.

Richardson DHS, RP Cameron. 2004. Cyanolichens: their response to pollution and possible management strategies for their conservation in northeastern North America. Northeast Naturalist 11: 1-22.

Scheidegger C, S Werth. 2009. Conservation strategies for lichens: insights from population biology. Fungal Biological Review 23: 55-66.

Topham P. 1977. Colonization, Growth, Sucession and Competion, in M.R.D. Seaward (ed.) Lichen Ecology. Academic Press, London.

Tuvi EL, A Vellak, Ü Reier, R Szava-Kovats, M Pärtel. 2011. Establishment of protected areas in different ecoregions, ecosystems, and diversity hotspots under successive political systems. Biological Conservation 144: 1726-1732.

Valencia MC de, JA Ceballos. 2002. Hongos liquenizados, Bogotá, Colombia. Universidad Nacional de Colombia

Wolseley PA. 1991. Observations on the composition and distribution of the 'Lobarion' in forest of south east Asia. In Galloway DJ ed. Tropical lichens: their systematic. Association special, Oxford. UK. Clarendon Press. p. 217-243.

World Bird Watch. 2012. Protecting the Pampas. June 2012. Available from http://www.savebrasil.org.br Accessed 22 Aug. 2013. 
Appendix. Lichen species found in all riparian forest stand with abundance values for each one. LO1-LO6: Lolita Farmland, MA1MA3: São Maurício Farmland and RB1-RB3: Rincão Bonito Farmland. Taxa prepended by an asterisk $(*)$ indicated a new citation for the South America, Brazil and the state of Rio Grande do Sul.

\begin{tabular}{|c|c|c|c|c|c|c|c|c|c|c|c|c|}
\hline \multirow{2}{*}{ Taxa } & \multicolumn{12}{|c|}{ Riparian forest stands } \\
\hline & LO1 & $\mathrm{LO} 2$ & LO3 & LO4 & LO5 & LO6 & MA1 & MA2 & MA3 & RB1 & $\mathrm{RB} 2$ & RB3 \\
\hline Anisomeridium sp. $1^{*}$ & 0 & 0 & 0 & 0 & 0 & 0 & 2 & 0 & 0 & 0 & 0 & 0 \\
\hline Anisomeridium sp.2* & 0 & 1 & 0 & 0 & 0 & 0 & 0 & 0 & 0 & 0 & 0 & 0 \\
\hline $\begin{array}{l}\text { Anthracothecium prasinum (Eschw.) } \\
\text { R. C. Harris }\end{array}$ & 0 & 0 & 0 & 0 & 0 & 0 & 0 & 0 & 2 & 0 & 0 & 0 \\
\hline Astrothelium sp.* & 0 & 1 & 0 & 0 & 0 & 0 & 0 & 0 & 0 & 0 & 0 & 0 \\
\hline Bacidia alutacea (Kremplh.) Zahlbr. & 0 & 0 & 0 & 0 & 0 & 0 & 0 & 0 & 0 & 0 & 1 & 5 \\
\hline $\begin{array}{l}\text { Bacidia fluminensis (Malme) } \\
\text { Cáceres et Lücking }\end{array}$ & 0 & 0 & 0 & 0 & 0 & 3 & 3 & 15 & 1 & 0 & 9 & 0 \\
\hline Bacidia russeola (Kremp.) Zahlbr. & 7 & 0 & 0 & 0 & 0 & 13 & 0 & 0 & 3 & 0 & 3 & 7 \\
\hline Bacidia subtestacea Malme & 0 & 0 & 0 & 0 & 0 & 0 & 0 & 0 & 0 & 0 & 0 & 2 \\
\hline Bacidia sp.1* & 0 & 0 & 0 & 0 & 0 & 0 & 1 & 0 & 0 & 0 & 6 & 0 \\
\hline Bapalmuia sp.* & 0 & 0 & 0 & 0 & 0 & 0 & 0 & 0 & 0 & 0 & 0 & 2 \\
\hline $\begin{array}{l}\text { Brigantiaea leucoxantha (Spreng.) } \\
\text { R. Sant. et Hafellner }\end{array}$ & 27 & 13 & 0 & 0 & 2 & 0 & 0 & 3 & 1 & 0 & 4 & 4 \\
\hline Calopadia sp.* & 0 & 0 & 2 & 0 & 0 & 0 & 0 & 0 & 0 & 0 & 0 & 0 \\
\hline Caloplaca erythranta (Tuck.) Zahlbr. & 0 & 0 & 0 & 0 & 0 & 0 & 0 & 1 & 1 & 0 & 0 & 0 \\
\hline Caloplaca sp. & 0 & 0 & 0 & 0 & 0 & 0 & 1 & 0 & 0 & 0 & 0 & 0 \\
\hline Canoparmelia caroliniana (Nyl.) Elix et Hale & 0 & 1 & 0 & 0 & 0 & 0 & 0 & 3 & 0 & 0 & 0 & 0 \\
\hline $\begin{array}{l}\text { Canoparmelia roseoreagens } \\
\text { Marcelli et Canêz }\end{array}$ & 0 & 0 & 0 & 0 & 0 & 0 & 0 & 1 & 0 & 0 & 0 & 0 \\
\hline Canoparmelia texana (Tuck.) Elix et Hale & 0 & 0 & 0 & 1 & 0 & 0 & 1 & 1 & 0 & 1 & 0 & 0 \\
\hline $\begin{array}{l}\text { Chapsa chionostoma (Nyl.) } \\
\text { Rivas-Plata et Mangold }\end{array}$ & 0 & 0 & 0 & 0 & 0 & 0 & 3 & 2 & 0 & 0 & 0 & 0 \\
\hline Chapsa sp. & 0 & 0 & 0 & 0 & 0 & 0 & 0 & 0 & 0 & 0 & 2 & 0 \\
\hline $\begin{array}{l}\text { Coccocarpia erythroxyli (Sprengel) } \\
\text { Sw. et Krog }\end{array}$ & 0 & 0 & 0 & 0 & 0 & 0 & 0 & 10 & 0 & 0 & 0 & 0 \\
\hline Coccocarpia pellita (Ach.) Müll.Arg. & 0 & 0 & 0 & 0 & 0 & 0 & 4 & 0 & 0 & 0 & 0 & 0 \\
\hline Coccocarpia stellata Tuck. & 0 & 0 & 0 & 0 & 0 & 0 & 2 & 0 & 0 & 0 & 0 & 0 \\
\hline Coenogonium interplexum Nyl. & 0 & 0 & 0 & 0 & 0 & 0 & 0 & 0 & 0 & 0 & 1 & 0 \\
\hline $\begin{array}{l}\text { Coenogonium subdilutum (Malme) } \\
\text { Lücking, Aptroot et Sipman }\end{array}$ & 0 & 12 & 0 & 0 & 0 & 0 & 0 & 0 & 0 & 0 & 0 & 0 \\
\hline Coenogonium sp. 1 & 0 & 0 & 0 & 0 & 0 & 1 & 0 & 0 & 0 & 0 & 0 & 0 \\
\hline Coenogonium sp. 2* & 0 & 0 & 0 & 0 & 8 & 0 & 0 & 0 & 0 & 0 & 0 & 0 \\
\hline Coenogonium sp. 3* & 0 & 0 & 0 & 1 & 0 & 0 & 0 & 0 & 0 & 0 & 1 & 0 \\
\hline Coenogonium sp.4* & 0 & 0 & 0 & 0 & 0 & 0 & 0 & 0 & 2 & 0 & 0 & 0 \\
\hline Collema fasciculare (L.) Wigg. & 0 & 0 & 6 & 0 & 3 & 0 & 0 & 3 & 0 & 0 & 0 & 0 \\
\hline $\begin{array}{l}\text { Crespoa carneopruinata (Zahlbr.) } \\
\text { Lendemer et Hodkinson }\end{array}$ & 0 & 41 & 5 & 5 & 9 & 23 & 31 & 53 & 19 & 35 & 5 & 19 \\
\hline Crocodia aurata (Ach.) Link & 2 & 9 & 39 & 0 & 3 & 2 & 5 & 0 & 0 & 12 & 11 & 22 \\
\hline Crocodia clathrata (De Not.) Trevis. & 0 & 1 & 5 & 0 & 3 & 11 & 1 & 0 & 2 & 1 & 0 & 1 \\
\hline Diorygma sp.* & 2 & 1 & 0 & 7 & 44 & 7 & 0 & 0 & 0 & 0 & 0 & 2 \\
\hline Dirinaria picta (Sw.) Clements et Shear & 0 & 1 & 0 & 0 & 0 & 0 & 7 & 2 & 9 & 5 & 1 & 3 \\
\hline Glyphis cicatricosa (Ach.) Vain. & 2 & 0 & 0 & 0 & 0 & 0 & 0 & 2 & 0 & 0 & 0 & 0 \\
\hline
\end{tabular}


Appendix continued

\begin{tabular}{|c|c|c|c|c|c|c|c|c|c|c|c|c|}
\hline Graphis calcea (Fée) A. Massal. & 3 & 18 & 0 & 0 & 0 & 2 & 0 & 0 & 0 & 5 & 23 & 4 \\
\hline Graphis consanguinea (Müll.Arg.) Lücking & 0 & 0 & 0 & 0 & 0 & 0 & 0 & 2 & 0 & 0 & 0 & 0 \\
\hline Graphis dolichographa Nyl. & 0 & 0 & 0 & 0 & 0 & 4 & 2 & 4 & 0 & 0 & 0 & 0 \\
\hline Graphis paraserpens Lizano et Lücking & 0 & 8 & 0 & 0 & 0 & 0 & 0 & 0 & 0 & 0 & 0 & 0 \\
\hline Graphis rimulosa (Mont.) Trevis. & 0 & 0 & 0 & 0 & 0 & 0 & 0 & 5 & 0 & 0 & 0 & 0 \\
\hline Graphis sp. 1* & 0 & 0 & 0 & 0 & 0 & 2 & 0 & 0 & 0 & 5 & 23 & 4 \\
\hline Graphis sp. 2 & 0 & 1 & 0 & 0 & 0 & 0 & 0 & 0 & 0 & 0 & 0 & 0 \\
\hline Graphis sp. 3* & 0 & 9 & 0 & 6 & 1 & 0 & 0 & 0 & 0 & 0 & 1 & 1 \\
\hline Graphis sp. 4* & 0 & 0 & 0 & 0 & 0 & 0 & 2 & 0 & 0 & 0 & 0 & 0 \\
\hline Graphis sp.5* & 0 & 1 & 0 & 0 & 0 & 1 & 0 & 4 & 0 & 0 & 0 & 0 \\
\hline Graphis sp. 6 * & 0 & 0 & 0 & 0 & 0 & 0 & 0 & 1 & 0 & 0 & 0 & 0 \\
\hline Grupo Lepraria sp. & 0 & 0 & 0 & 0 & 0 & 0 & 0 & 0 & 2 & 1 & 3 & 0 \\
\hline Haematomma sp.* & 0 & 0 & 0 & 0 & 0 & 0 & 1 & 5 & 0 & 0 & 0 & 0 \\
\hline Hemithecium chlorocarpum (Fée) Trev. & 0 & 3 & 0 & 0 & 0 & 0 & 0 & 27 & 0 & 0 & 0 & 0 \\
\hline $\begin{array}{l}\text { Herpothallon rubrocinctum (Ehrenb.) } \\
\text { Aptroot et Lücking }\end{array}$ & 0 & 6 & 0 & 51 & 24 & 0 & 0 & 0 & 0 & 6 & 0 & 0 \\
\hline $\begin{array}{l}\text { Heterodermia albicans (Pers.) } \\
\text { Swinsc. et Krog }\end{array}$ & 0 & 0 & 0 & 0 & 6 & 0 & 1 & 11 & 1 & 11 & 0 & 5 \\
\hline Heterodermia casarettiana (Massal.) Trevis & 0 & 0 & 0 & 0 & 0 & 0 & 0 & 0 & 0 & 0 & 15 & 8 \\
\hline Heterodermia diademata (Taylor) Awasthi & 0 & 7 & 0 & 0 & 1 & 0 & 0 & 7 & 2 & 0 & 2 & 0 \\
\hline Heterodermia cf. diademata (Taylor) Awasthi & 0 & 2 & 0 & 0 & 0 & 0 & 0 & 2 & 0 & 0 & 0 & 0 \\
\hline Heterodermia flabellata (Fée) Awasthi & 0 & 0 & 0 & 0 & 0 & 0 & 0 & 0 & 0 & 0 & 0 & 1 \\
\hline Heterodermia leucomela (L.) Poelt & 12 & 0 & 0 & 0 & 0 & 0 & 3 & 0 & 1 & 5 & 3 & 0 \\
\hline Heterodermia lutescens (Kurok.) Follmann & 0 & 0 & 0 & 0 & 0 & 0 & 5 & 0 & 0 & 3 & 2 & 13 \\
\hline Heterodermia obscurata (Nyl.) Trevis & 57 & 33 & 88 & 19 & 63 & 129 & 179 & 97 & 150 & 113 & 88 & 117 \\
\hline $\begin{array}{l}\text { Heterodermia pseudospeciosa (Kurok.) } \\
\text { W.L. Culb. }\end{array}$ & 0 & 0 & 0 & 0 & 0 & 0 & 0 & 0 & 0 & 1 & 0 & 0 \\
\hline $\begin{array}{l}\text { Heterodermia cf. pseudospeciosa (Kurok.) } \\
\text { W.L. Culb. }\end{array}$ & 0 & 3 & 0 & 0 & 0 & 0 & 0 & 0 & 0 & 0 & 0 & 0 \\
\hline Heterodermia speciosa (Wulf.) Trevis & 0 & 0 & 0 & 2 & 0 & 0 & 4 & 4 & 0 & 9 & 22 & 2 \\
\hline Heterodermia sp. $1^{*}$ & 3 & 0 & 0 & 0 & 0 & 0 & 0 & 0 & 0 & 0 & 0 & 0 \\
\hline $\begin{array}{l}\text { Heterodermia vulgaris (Vain.) } \\
\text { Follmann et Redón }\end{array}$ & 16 & 5 & 11 & 0 & 3 & 5 & 9 & 3 & 0 & 7 & 19 & 7 \\
\hline $\begin{array}{l}\text { Hyperphyscia adglutinata (Flörke) } \\
\text { H. Mayrhofer et Poelt }\end{array}$ & 0 & 0 & 0 & 0 & 3 & 0 & 0 & 0 & 0 & 0 & 0 & 0 \\
\hline Hyperphyscia syncolla (Tuck.) Kalb & 0 & 0 & 0 & 0 & 0 & 0 & 2 & 0 & 0 & 0 & 0 & 0 \\
\hline Hyperphyscia sp.* & 0 & 0 & 0 & 2 & 0 & 0 & 0 & 0 & 0 & 0 & 0 & 0 \\
\hline Hypotrachyna livida (Taylor) Hale & 4 & 4 & 0 & 0 & 3 & 1 & 6 & 23 & 0 & 0 & 1 & 3 \\
\hline $\begin{array}{l}\text { Hypotrachyna polydactyla } \\
\text { (Krog et Swinsc.) Nash }\end{array}$ & 0 & 0 & 0 & 0 & 0 & 0 & 0 & 10 & 0 & 0 & 0 & 0 \\
\hline $\begin{array}{l}\text { Hypotrachyna cf. polydactyla } \\
\text { (Krog et Swinsc.) Nash }\end{array}$ & 0 & 1 & 0 & 0 & 0 & 0 & 0 & 0 & 0 & 0 & 0 & 0 \\
\hline Lecanora grupo subfusca (L.) Ach. & 0 & 0 & 0 & 0 & 0 & 0 & 0 & 4 & 0 & 3 & 1 & 0 \\
\hline Lecanora achroa Nyl. & 0 & 0 & 11 & 0 & 0 & 0 & 0 & 3 & 6 & 0 & 0 & 0 \\
\hline Lecanora albella (Pers.) Ach. & 2 & 0 & 0 & 0 & 0 & 0 & 9 & 0 & 2 & 0 & 18 & 0 \\
\hline Lecanora concilianda Vain. & 0 & 0 & 0 & 0 & 0 & 0 & 0 & 19 & 0 & 0 & 0 & 0 \\
\hline Lecanora sp.* & 0 & 0 & 0 & 0 & 0 & 0 & 0 & 0 & 0 & 0 & 0 & 1 \\
\hline
\end{tabular}


Appendix continued

\begin{tabular}{|c|c|c|c|c|c|c|c|c|c|c|c|c|}
\hline $\begin{array}{l}\text { Leptogium austroamericanum (Malme) } \\
\text { Dodge }\end{array}$ & 0 & 0 & 0 & 0 & 0 & 0 & 0 & 0 & 0 & 1 & 0 & 0 \\
\hline Leptogium azureum (Sw.) Mont. & 0 & 0 & 20 & 0 & 4 & 21 & 19 & 4 & 2 & 0 & 9 & 11 \\
\hline $\begin{array}{l}\text { Leptogium cochleatum (Dicks.) } \\
\text { P.M. Jorg. et P. James }\end{array}$ & 0 & 3 & 0 & 0 & 0 & 0 & 0 & 0 & 0 & 0 & 0 & 0 \\
\hline Leptogium cyanescens (Rabenh.) Körb. & 0 & 0 & 3 & 0 & 7 & 7 & 0 & 0 & 0 & 0 & 4 & 0 \\
\hline Leptogium denticulatum Nyl. & 0 & 7 & 0 & 0 & 0 & 0 & 0 & 0 & 0 & 0 & 0 & 0 \\
\hline Leptogium isidiosellum (Ridd.) Sierk & 0 & 0 & 0 & 0 & 0 & 0 & 0 & 0 & 1 & 3 & 2 & 1 \\
\hline Leptogium phyllocarpum (Pers.) Mont. & 0 & 0 & 18 & 0 & 0 & 0 & 2 & 0 & 18 & 0 & 7 & 20 \\
\hline Leptogium sp. $1^{*}$ & 0 & 0 & 40 & 0 & 0 & 0 & 0 & 0 & 0 & 0 & 0 & 0 \\
\hline Leptogium sp. 2 * & 0 & 0 & 0 & 0 & 0 & 4 & 0 & 0 & 0 & 6 & 0 & 0 \\
\hline Lobaria discolor (Bory ex Delise) Hue & 0 & 0 & 0 & 0 & 0 & 0 & 0 & 0 & 0 & 2 & 10 & 56 \\
\hline Lobaria erosa (Eschw.) Nyl. & 0 & 25 & 13 & 3 & 21 & 34 & 16 & 0 & 14 & 28 & 20 & 3 \\
\hline Lobaria intermedia (Nyl.) Vain. & 0 & 0 & 0 & 1 & 0 & 0 & 0 & 0 & 0 & 0 & 0 & 0 \\
\hline Lobaria patinifera (Taylor) Hue & 0 & 0 & 0 & 0 & 0 & 0 & 0 & 0 & 0 & 0 & 0 & 3 \\
\hline $\begin{array}{l}\text { Malmidea vinosa (Eschw.) Kalb, } \\
\text { Rivas Plata et Lumbsch }\end{array}$ & 0 & 2 & 0 & 0 & 0 & 0 & 0 & 0 & 0 & 0 & 0 & 0 \\
\hline Malmidea sp. 1 * & 0 & 22 & 0 & 0 & 0 & 0 & 0 & 0 & 0 & 1 & 0 & 1 \\
\hline Malmidea sp. 2 * & 16 & 0 & 0 & 0 & 0 & 0 & 0 & 0 & 0 & 0 & 0 & 0 \\
\hline Myelochroa lindmanii (Lynge) Elix et Hale & 0 & 3 & 0 & 0 & 0 & 0 & 0 & 0 & 0 & 0 & 4 & 0 \\
\hline Normandina pulchella (Borrer) Nyl. & 0 & 0 & 1 & 0 & 0 & 0 & 0 & 6 & 0 & 0 & 0 & 4 \\
\hline Ochrolechia pallescens (L.) Massal. & 0 & 0 & 0 & 0 & 0 & 0 & 1 & 0 & 0 & 0 & 0 & 0 \\
\hline Opegrapha sp. 1 & 0 & 1 & 0 & 0 & 0 & 0 & 1 & 0 & 0 & 0 & 0 & 0 \\
\hline Parmelinopsis minarum (Vain.) Elix et Hale & 0 & 11 & 0 & 0 & 1 & 1 & 1 & 20 & 0 & 0 & 0 & 0 \\
\hline Parmelinopsis sp. & 0 & 0 & 0 & 0 & 0 & 0 & 0 & 4 & 0 & 0 & 0 & 0 \\
\hline Parmotrema catarinae Hale & 0 & 0 & 1 & 0 & 0 & 0 & 2 & 0 & 0 & 1 & 0 & 0 \\
\hline Parmotrema cetratum (Ach.) Hale & 36 & 14 & 0 & 12 & 5 & 11 & 60 & 80 & 25 & 34 & 14 & 18 \\
\hline $\begin{array}{l}\text { Parmotrema clavuliferum (Räsänen) } \\
\text { Streimann }\end{array}$ & 0 & 0 & 0 & 0 & 5 & 2 & 3 & 0 & 0 & 0 & 1 & 6 \\
\hline $\begin{array}{l}\text { Parmotrema consors (Kremp.) } \\
\text { Spielmann et Marcelli }\end{array}$ & 0 & 0 & 0 & 0 & 0 & 0 & 1 & 6 & 31 & 8 & 1 & 0 \\
\hline Parmotrema ecilatum (Nyl.) Hale & 0 & 0 & 1 & 9 & 0 & 0 & 0 & 0 & 0 & 0 & 18 & 1 \\
\hline Parmotrema cf. eurysacum (Hue) Hale & 0 & 0 & 19 & 0 & 0 & 0 & 0 & 0 & 0 & 0 & 0 & 0 \\
\hline Parmotrema haitiense (Hale) Hale & 0 & 9 & 0 & 0 & 0 & 0 & 0 & 0 & 0 & 0 & 0 & 0 \\
\hline $\begin{array}{l}\text { Parmotrema internexum (Nyl.) } \\
\text { Hale ex De Priest et B.W. Hale }\end{array}$ & 0 & 0 & 1 & 0 & 0 & 0 & 0 & 0 & 0 & 0 & 0 & 0 \\
\hline Parmotrema melanothrix (Mont.) Hale & 1 & 0 & 0 & 0 & 0 & 0 & 4 & 0 & 0 & 2 & 1 & 8 \\
\hline Parmotrema mellissii (Dodge) Hale & 0 & 0 & 0 & 0 & 0 & 0 & 0 & 0 & 0 & 0 & 2 & 0 \\
\hline $\begin{array}{l}\text { Parmotrema muelleri (Vain.) } \\
\text { Blanco, Crespo, Divakar, Elix et Lumbsch }\end{array}$ & 0 & 0 & 0 & 0 & 0 & 0 & 0 & 0 & 0 & 1 & 0 & 0 \\
\hline $\begin{array}{l}\text { Parmotrema pilosum (Stizenb.) } \\
\text { Krog et Swinscow }\end{array}$ & 0 & 0 & 5 & 14 & 0 & 0 & 0 & 0 & 0 & 1 & 0 & 0 \\
\hline Parmotrema praesorediosum (Nyl.) Hale & 1 & 0 & 6 & 0 & 0 & 0 & 0 & 0 & 0 & 0 & 0 & 0 \\
\hline Parmotrema cf. rampoddense (Nyl.) Hale & 0 & 0 & 0 & 0 & 1 & 0 & 0 & 0 & 0 & 0 & 0 & 0 \\
\hline Parmotrema recipiendum (Nyl.) Hale & 0 & 0 & 0 & 0 & 0 & 3 & 0 & 4 & 1 & 2 & 0 & 0 \\
\hline Parmotrema reticulatum (Taylor) M. Choisy & 37 & 20 & 11 & 0 & 4 & 4 & 23 & 0 & 31 & 23 & 4 & 17 \\
\hline Parmotrema rigidum (Lynge) Hale & 0 & 0 & 0 & 0 & 0 & 0 & 3 & 0 & 0 & 0 & 4 & 3 \\
\hline
\end{tabular}


Appendix continued

\begin{tabular}{|c|c|c|c|c|c|c|c|c|c|c|c|c|}
\hline Parmotrema sancti-angeli (Lynge) Hale & 0 & 0 & 0 & 0 & 0 & 0 & 0 & 0 & 2 & 0 & 0 & 0 \\
\hline Parmotrema simulans (Hale) Hale & 0 & 0 & 0 & 0 & 0 & 0 & 0 & 0 & 1 & 0 & 0 & 0 \\
\hline Parmotrema subcaperatum (Kremp.) Hale & 4 & 0 & 0 & 0 & 0 & 0 & 3 & 3 & 5 & 4 & 2 & 0 \\
\hline Parmotrema subrugatum (Kremp.) Hale & 0 & 0 & 8 & 16 & 0 & 0 & 9 & 0 & 0 & 0 & 2 & 0 \\
\hline Parmotrema tinctorum (Nyl.) Hale & 0 & 0 & 0 & 0 & 0 & 0 & 0 & 0 & 0 & 0 & 0 & 1 \\
\hline Pertusaria carneola (Eschw.) Müll.Arg. & 0 & 0 & 0 & 0 & 0 & 0 & 0 & 6 & 0 & 0 & 0 & 0 \\
\hline Pertusaria flavens Nyl. & 0 & 0 & 0 & 0 & 0 & 0 & 0 & 0 & 0 & 0 & 1 & 0 \\
\hline Pertusaria velata (Turner) Nyl. & 0 & 1 & 0 & 0 & 0 & 0 & 0 & 0 & 0 & 0 & 0 & 0 \\
\hline Pertusaria sp. 1 & 0 & 2 & 0 & 0 & 0 & 0 & 0 & 0 & 0 & 0 & 0 & 0 \\
\hline Pertusaria sp. 2 & 0 & 0 & 0 & 1 & 0 & 0 & 0 & 0 & 0 & 0 & 0 & 0 \\
\hline Pertusaria sp. 3 & 0 & 0 & 0 & 0 & 0 & 0 & 0 & 0 & 0 & 0 & 0 & 1 \\
\hline Pertusaria sp. 4 & 0 & 0 & 0 & 0 & 0 & 0 & 0 & 7 & 0 & 0 & 0 & 0 \\
\hline Phaeographis lecanographa (Nyl.) Staiger & 0 & 0 & 0 & 0 & 0 & 0 & 0 & 2 & 0 & 0 & 0 & 0 \\
\hline Phlyctella brasiliensis (Nyl.) Nyl. & 0 & 0 & 4 & 0 & 0 & 0 & 0 & 0 & 0 & 1 & 0 & 0 \\
\hline Phyllopsora breviuscula (Nyl.) Müll. Arg. & 0 & 0 & 0 & 27 & 3 & 0 & 0 & 0 & 0 & 5 & 0 & 0 \\
\hline Phyllopsora buettneri (Müll.Arg.) Zahlbr. & 0 & 0 & 0 & 0 & 0 & 0 & 0 & 0 & 0 & 2 & 5 & 0 \\
\hline Phyllopsora chlorophaea (Müll.arg.) Zahlbr. & 0 & 0 & 0 & 0 & 0 & 4 & 0 & 0 & 0 & 0 & 0 & 0 \\
\hline Phyllopsora confusa Swinsc. et Krog & 0 & 0 & 0 & 0 & 2 & 0 & 0 & 0 & 0 & 0 & 0 & 0 \\
\hline Phyllopsora furfuraceae (Pers.) Zahlbr. & 0 & 0 & 0 & 0 & 0 & 0 & 0 & 0 & 0 & 1 & 0 & 0 \\
\hline Phyllopsora sp. * & 0 & 0 & 0 & 0 & 0 & 0 & 0 & 0 & 0 & 0 & 0 & 1 \\
\hline Physcia aipolia (Humb.) Fürnr. & 0 & 4 & 0 & 0 & 0 & 0 & 0 & 12 & 0 & 2 & 2 & 0 \\
\hline Physcia alba (Fée) Müll.rg. & 0 & 0 & 0 & 0 & 0 & 0 & 0 & 5 & 0 & 0 & 0 & 0 \\
\hline Physcia atrostriata Moberg & 0 & 40 & 8 & 22 & 9 & 27 & 15 & 5 & 4 & 23 & 28 & 2 \\
\hline Physcia crispa Nyl. & 0 & 0 & 0 & 0 & 1 & 0 & 0 & 0 & 0 & 0 & 0 & 0 \\
\hline Physcia krogiae Moberg & 0 & 0 & 0 & 0 & 0 & 0 & 0 & 1 & 0 & 0 & 0 & 0 \\
\hline Physcia poncinsii Hue & 0 & 0 & 0 & 0 & 0 & 0 & 0 & 0 & 3 & 4 & 0 & 0 \\
\hline Physcia sorediosa (Vain.) Lynge & 0 & 0 & 0 & 7 & 0 & 0 & 0 & 3 & 0 & 0 & 0 & 0 \\
\hline Physcia tribacoides Nyl. & 0 & 0 & 0 & 0 & 0 & 0 & 0 & 20 & 0 & 0 & 0 & 0 \\
\hline Physcia undulata Moberg & 0 & 0 & 0 & 0 & 0 & 4 & 0 & 0 & 0 & 0 & 0 & 5 \\
\hline Physcia sp. $1 *$ & 0 & 0 & 0 & 0 & 0 & 3 & 0 & 0 & 0 & 0 & 0 & 0 \\
\hline Physcia sp. $2 *$ & 0 & 0 & 0 & 0 & 0 & 0 & 0 & 3 & 0 & 0 & 0 & 0 \\
\hline Platygramme caesiopruinosa (Fée) Fée & 0 & 0 & 0 & 0 & 0 & 0 & 1 & 2 & 0 & 0 & 1 & 0 \\
\hline Porina africana Müll. Arg. & 0 & 0 & 0 & 0 & 0 & 0 & 0 & 0 & 0 & 10 & 0 & 0 \\
\hline $\begin{array}{l}\text { Pseudocyphellaria aff. clathrata (De Not.) } \\
\text { Malme }\end{array}$ & 0 & 4 & 0 & 0 & 0 & 0 & 0 & 0 & 0 & 0 & 0 & 0 \\
\hline Pseudocyphellaria sp. & 0 & 0 & 0 & 0 & 0 & 0 & 0 & 0 & 0 & 1 & 0 & 0 \\
\hline Psoroglaena sp. * & 0 & 0 & 0 & 0 & 0 & 0 & 0 & 0 & 0 & 0 & 4 & 0 \\
\hline Punctelia bolliana (Müll.Arg.) Krog & 0 & 0 & 0 & 6 & 0 & 0 & 0 & 0 & 0 & 0 & 0 & 0 \\
\hline Punctelia constantimontium Sérus. & 1 & 0 & 23 & 0 & 0 & 0 & 6 & 0 & 0 & 1 & 0 & 0 \\
\hline Punctelia fimbriata Marcelli et Canêz & 0 & 0 & 0 & 0 & 11 & 0 & 0 & 0 & 0 & 0 & 0 & 0 \\
\hline Punctelia graminicola (B. de Lesd.) Egan & 0 & 0 & 0 & 0 & 0 & 0 & 0 & 0 & 0 & 0 & 1 & 0 \\
\hline Punctelia hypoleucites Nyl. & 3 & 3 & 0 & 0 & 0 & 0 & 0 & 0 & 0 & 0 & 0 & 0 \\
\hline Punctelia microsticta (Müll.Arg.) Krog & 0 & 0 & 0 & 0 & 0 & 0 & 0 & 0 & 1 & 0 & 10 & 0 \\
\hline Punctelia osorioi Canêz et Marcelli & 0 & 0 & 0 & 0 & 0 & 0 & 14 & 0 & 0 & 0 & 0 & 0 \\
\hline
\end{tabular}


Appendix continued

\begin{tabular}{|c|c|c|c|c|c|c|c|c|c|c|c|c|}
\hline Punctelia riograndensis (Lynge) Krog & 0 & 0 & 2 & 0 & 0 & 0 & 0 & 0 & 0 & 0 & 0 & 0 \\
\hline Punctelia sp. 1 & 0 & 0 & 0 & 0 & 15 & 0 & 0 & 5 & 9 & 14 & 14 & 9 \\
\hline Punctelia sp. 2 & 20 & 3 & 0 & 0 & 15 & 0 & 0 & 15 & 21 & 0 & 13 & 0 \\
\hline Punctelia sp. 3 & 0 & 0 & 0 & 17 & 0 & 0 & 9 & 0 & 0 & 0 & 0 & 0 \\
\hline Punctelia sp. 4 * & 0 & 0 & 0 & 0 & 0 & 2 & 0 & 0 & 0 & 0 & 0 & 0 \\
\hline Punctelia sp. 5 & 0 & 16 & 1 & 51 & 38 & 0 & 2 & 43 & 6 & 21 & 44 & 34 \\
\hline Punctelia sp. 6 & 0 & 2 & 0 & 0 & 0 & 0 & 0 & 0 & 0 & 0 & 0 & 0 \\
\hline Punctelia sp. 7 & 0 & 0 & 0 & 9 & 0 & 0 & 0 & 0 & 1 & 32 & 6 & 0 \\
\hline Punctelia sp. 8 & 0 & 0 & 0 & 1 & 0 & 0 & 0 & 0 & 0 & 0 & 0 & 0 \\
\hline Punctelia sp. 9 & 0 & 0 & 0 & 0 & 1 & 0 & 0 & 0 & 0 & 0 & 0 & 0 \\
\hline Punctelia sp. 10 & 0 & 0 & 0 & 0 & 8 & 0 & 0 & 0 & 0 & 0 & 0 & 0 \\
\hline Pyrenula sp. * & 5 & 0 & 0 & 0 & 0 & 0 & 0 & 0 & 0 & 0 & 0 & 0 \\
\hline Pyrenula mucosa (Vain.) R.C. Harris & 0 & 0 & 0 & 0 & 0 & 0 & 0 & 0 & 0 & 0 & 1 & 0 \\
\hline Pyrenula pyrenuloides (Mont.) R.C.Harris & 0 & 0 & 0 & 0 & 0 & 0 & 6 & 0 & 0 & 0 & 0 & 0 \\
\hline Pyxine cocoës (Sw.) Nyl. & 0 & 0 & 0 & 0 & 0 & 0 & 0 & 1 & 0 & 0 & 0 & 4 \\
\hline Pyxine daedalea Krog et Santesson & 0 & 0 & 0 & 0 & 0 & 0 & 0 & 0 & 0 & 0 & 0 & 11 \\
\hline Pyxine subcinerea Stirton & 0 & 0 & 0 & 0 & 0 & 0 & 2 & 14 & 4 & 0 & 0 & 0 \\
\hline $\begin{array}{l}\text { Ramalina celastri (Spreng.) Krog et } \\
\text { Swinscow }\end{array}$ & 5 & 0 & 21 & 16 & 0 & 0 & 0 & 0 & 0 & 2 & 11 & 0 \\
\hline Ramalina peruviana Ach. & 4 & 0 & 5 & 0 & 9 & 0 & 0 & 0 & 60 & 23 & 77 & 10 \\
\hline Ramalina sprengelli Krog et Swinscow & 0 & 0 & 1 & 0 & 0 & 0 & 0 & 0 & 0 & 2 & 6 & 0 \\
\hline Ramalina usnea (L.) Howe & 0 & 0 & 3 & 0 & 0 & 0 & 0 & 0 & 0 & 0 & 0 & 0 \\
\hline Teloschistes exilis (Michx.) Vain. & 5 & 0 & 0 & 0 & 0 & 0 & 4 & 5 & 10 & 4 & 7 & 3 \\
\hline Tephromela americana (Fée) Kalb & 1 & 0 & 0 & 0 & 0 & 0 & 0 & 0 & 0 & 0 & 0 & 7 \\
\hline Trichothelium sp.* & 0 & 1 & 0 & 2 & 0 & 0 & 0 & 0 & 0 & 0 & 0 & 2 \\
\hline $\begin{array}{l}\text { Trypethelium nitidiusculum (Nyl.) } \\
\text { R. C. Harris }\end{array}$ & 1 & 5 & 0 & 0 & 0 & 0 & 0 & 0 & 0 & 0 & 0 & 1 \\
\hline Trypethelium sp. * & 0 & 0 & 0 & 0 & 0 & 0 & 0 & 0 & 6 & 0 & 0 & 0 \\
\hline Usnea angulata Ach. & 0 & 0 & 0 & 0 & 0 & 0 & 0 & 0 & 0 & 8 & 1 & 4 \\
\hline Usnea cf. rubicunda Stirton & 0 & 0 & 0 & 0 & 0 & 0 & 0 & 0 & 0 & 10 & 0 & 5 \\
\hline Usnea florida (L.) Wigg. & 0 & 0 & 0 & 0 & 0 & 0 & 0 & 0 & 0 & 0 & 1 & 0 \\
\hline Usnea rubicunda Stirton & 0 & 0 & 0 & 0 & 0 & 0 & 0 & 0 & 0 & 0 & 1 & 2 \\
\hline Usnea sp. 1 & 4 & 0 & 1 & 2 & 0 & 0 & 2 & 0 & 3 & 0 & 0 & 0 \\
\hline Usnea sp. 2 & 20 & 0 & 0 & 0 & 0 & 0 & 0 & 0 & 0 & 0 & 0 & 0 \\
\hline Usnea sp. 3 & 3 & 0 & 0 & 0 & 0 & 0 & 1 & 0 & 0 & 0 & 0 & 0 \\
\hline Usnea sp. 6 & 0 & 0 & 0 & 0 & 0 & 0 & 0 & 0 & 0 & 0 & 1 & 0 \\
\hline Usnea sp. 7 & 0 & 0 & 0 & 0 & 0 & 0 & 0 & 0 & 0 & 0 & 13 & 7 \\
\hline Usnea sp. 8 & 0 & 0 & 0 & 0 & 0 & 0 & 0 & 0 & 0 & 0 & 2 & 0 \\
\hline Usnea sp. 9 & 0 & 0 & 0 & 0 & 0 & 0 & 0 & 5 & 9 & 0 & 0 & 0 \\
\hline
\end{tabular}

